骨シンチグラフィにおいて， ${ }^{99 \mathrm{~m}} \mathrm{Tc}$-リン酸化合物は尿 中に排泄されるため，骨盤部特に膀胱部周辺の骨病変の 検出は不利とされてける. そこでわれわれは通常の RI 静注 $3 \sim 4$ 時間後の撮像に加えて24時間後の撮像（delayed scan) を行うことにより，膀胱部近傍の病巣の検 出に極めて有用であったので報告した。 ${ }^{99 m} \mathrm{Tc}$ リン酸化 合物を $10 \sim 20 \mathrm{mCi}$ 静注し，24時間後，骨盤部落前方加 ら撮像した。 ${ }^{99 \mathrm{~m}} \mathrm{Tc}$ は半減期が 6 時間であるため，かな り減衰しているか，CRT の輝度を上げるととにより， 充分診断可能な像を得ることができたまた，3時間後 像によく見られる排尿時の尿の下着への付着 (artifact) なよ゙竜除壮る利点がある。

\section{Autofluoroscope-Imager の使用経験}

秋田県立脳血管研究センタ一放射線科 ○蜂谷 武憲·底司 安明・羽上 栄二 相沢 康夫 - 小野寺 洋 - 管 幹雄 佳々木信夫

Autofluoroscope-Imager の使用経験につて報告し た.との結果, 総合分解能はコリメータ面で IAEA肝ス ライスファントム $5 \mathrm{~mm}$ の void を，バーファントムは $3 \mathrm{~mm}$, スターファントムは先端より約 $1 \mathrm{~cm}$ まで解像し た. $5 \mathrm{~cm}$ 厚のアクリル挿入では肺スライスファントム $1.2 \mathrm{~cm}$ の void をバーファントムは $5 \mathrm{~mm}$ を解像した. $0.6 \mathrm{~mm}$ の Line source 亿よる FWHM $3.6 \mathrm{~mm}$ でア クリ $5 \mathrm{~cm}$ では $10 \mathrm{~mm}$ で, とれの MTF す示した.

\section{[結論]}

分解能はスキャン機構により Autofluoroscope よりは はるかて改善された，実際の臨床検查では collimatorか らはタ出す臓器の集録やマルチディスプレイの機構は便

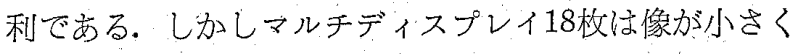
メリットは少なくない.

\section{5. 脳スキャンにおける頭部ガイドの検討}

下館市民病院放射線科 細川力

[目的]

脳のシンチスキャンニングの祭，不必要なスキャン面 をカットし操作時間を短縮し一層明暸なシンチグラムを 得るための一方法として頭部ガイド板法を試みた。

\section{[房法]}

エックス線写真から平均的な頭型を取りアクリル板を 切り抜いてガイド板とし患者に合わせて定盤䡩きカラ ースキャン用のアームを介してスキャナとマイクロスイ ッチを連動させた.ガイド板と合わない頭型の患者には 自在定規を用いてガイドとした.
〔結果】

一方向ずつ4面を撮影する從来の方法と比べて，本方 法によりスキャン時間を約 $1 / 3$ 短縮でき，患者の苦痛を軽 減し，視覚的コントラストの向上による読影にも嘪献し 得たので報告します。.

\section{1,000ホールコリメータのホール陰影の補正につい $\tau$}

\author{
順天堂大学医学部附属順天堂医院. \\ 中央放射線アイソトープ窒 \\ ○出中、政義・荒川佳也
}

\section{座長集約}

20席 (市波) は, フイルムの感度スペクトルと, シン テカメラ，スキャナの発光スペクトルの関係を取り投っ て抢り，21席（林）ではカメラの CRT 特性と各種フイ ルムにつにて対応検討している. 一般に各施設では，手 近にあるXレイフイルムやポラロイドフイルムをでく軽

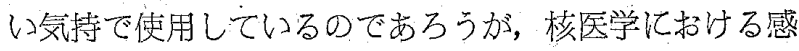
光材料への検討がより尃門的になされてあよい（大阪市 大，浜田）時期に至っている．20席に打汀る ASA 感度 をXレイフイルムに適用した点と，21席に抽る実験で の CRPの電気的特性の影響加検討事項として残った。 22原（吉富）の体内力リウム校正仿身長のみならず被検 者の厚みにつにても注意加必要（京大，古松）かと思わ

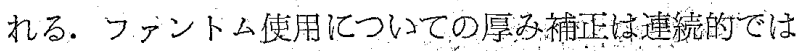
ないか测定䛮差（5\%程度）からみて十分なのであうう か. Delayer bone scan (23席，大村) については, 24 hr 後に恥骨部で RI 集積をみるとき，とれを異常イメー ジみてもよいの京大，藤田）との質問に，胃には イメージが残存してあ膀胱部には実際にRI が残ってい る経験をしていないと答えられた。この点は多くの施設 で検討した結果を今後もらよってもらいたいあのであ る. 24 席 (蜂谷) は, オートフルオロスコープのオプシ ョンであるイメージャの特長が述べられた. Preset time 方式でスキャナ時には測定さず，静此して測点するとと と，分割メイージの再合成が可能であるととの 2 点であ った. 分俥の合成はムービングベッドに工夫されている が, 体動・呼吸などで人工的偽像が生じる可能性（神奈 川，山本の質問飞答えて）ああるという．25席（細川） 脳スキャンにおける検查時間を短縮するための頭部ガイ ドの作成は，患者さんにとってす苦痛の軽娍であり,ひ とつの親切として好意をもちたい. とのガイドあ，大人 用 $2 \sim 3$ 枚，小人用もこの程度で十分間に合い，間に合 わない場合も自在定規で簡単に作用使用力就能（京大， 